\title{
The Dynamics of Islamic Ideology with Regard to Gender and Women's Education in South Asia
}

\author{
Forkan $A L I^{*}$
}

\begin{abstract}
The article presents an investigation on certain anthropological-social aspects and the social organization of women with a focus on female education and women's rights in Islam in South Asia, and especially in the subcontinent. It starts with the Moghul period and then turns to the colonial era and contemporary developments. Through the movement for independence from colonial rule of Britain, the Muslim identity in the South Asian region rose in a state of transformation, reform and development. This occurred due to several factors that encouraged the regeneration and reviewing of Indian society in response to the condemnation, discrimination and chauvinism of their colonial rulers and their deep-seated legacy. Women of the society, who were censured to be subjugated by the native men as entitled by colonial rulers, empowered this transformation by taking direct and indirect participation in it even though male-controlled norms and mind-sets have been a durable characteristic of South Asian society, impacting faith communities and social strata, including the Hindu, Buddhist and other non-Islamic traditions on the subcontinent. While religious arguments are generally used in efforts to preserve the asymmetrical position of men and women in economic, political, and social arenas, this investigation attempts to show that religious traditions in South Asia are not monolithic in their perceptions of gender and women's education. The structure of gender roles in these traditions is a consequence of various historical practices and ideological encouragements. Today, there is a substantial variability within and between religious communities concerning the social status of women. At different times and in different milieus, as studies shows, religious points of view have been deployed to validate male authority over women and, in opposition, to call for more impartial gender relations.
\end{abstract}

Keywords: women's education, Muslim identity, South Asia, gender roles, transformation of society

\section{Izvleček}

\section{Dinamika islamske ideologije glede na spol in izobraževanje žensk vjužni Aziji}

$\mathrm{V}$ prispevku je predstavljena raziskava nekaterih antropološko-socialnih vidikov in socialne organizacije žensk, ki se osredotoča na izobraževanje in pravice žensk v islamu v

Forkan ALI, Lecturer, Jhenaidah Government Veterinary College, Jessore University of Science and Technology, Bangladesh. forkanali.ali011[at]gmail.com

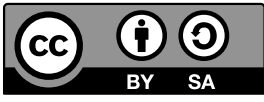


južni Aziji, posebej na Indijski podcelini. Začne z mogulskim obdobjem in se nadaljuje s kolonialnim obdobjem in obdobjem sodobnega razvoja. $Z$ gibanjem za neodvisnost od britanske kolonialne vladavine se je muslimanska identiteta na območju južne Azije preobrazila, reformirala in razvila. To se je zgodilo zaradi več dejavnikov, ki spodbujajo regeneracijo in prevpraševanje indijske družbe in so odgovor na obsodbo, diskriminacijo in šovinizem kolonialnih vladarjev in njihove globoko zakoreninjenene zapuščine. Ženski položaj v družbi je bil cenzuriran, da bi si jih lahko podredili lokalni moški, ki so to pravico dobili od kolonialnih vladarjev. Pozneje pa so ženske dobile moč in so se neposredno ali posredno vključile v družbo, kljub trdno zakoreninjenim patriarhalnimi normami in miselnosti v južnoazijskih državah, ki so prevevale vse verske skupnostih in družbene sloje, vključno s hinduizmom, budizmom in drugimi neislamskimi tradicijami na podcelini. Verski argumenti se običajno uporabljajo v prizadevanjih za ohranitev neenakega položaja moških in žensk v gospodarskih, političnih in socialnih sferah, ta raziskava pa poskuša pokazati, da verske tradicije v Južni Aziji niso enotne pri dojemanju spola in izobraževanja žensk. Struktura vloge spolov v teh tradicijah je posledica različnih zgodovinskih praks in ideoloških vplivov. Danes v verskih skupnostih obstajajo precejšne razlike, tudi glede družbenega statusa žensk. V različnih obdobjih in okoljih so verska stališča uporabljali za potrjevanje moške oblasti nad ženskami, pa tudi nasprotno, pri zahtevah po enakopravnejšem odnosu med spoloma.

Ključne besede: izobraževanje žensk, muslimanska identiteta, Vzhodna Azija, Južna Azija, vloga spolov, transformacija družbe

\section{Introduction-Inquiry of Rhetoric for a Return to the Noble Time}

The British Empire ruled over India for a long time and influenced the subcontinent socially, politically, economically, and most prominently, in terms of its consciousness. However, colonial rule then unhurriedly fell into decline with the drive for emancipation, and the independence movement of the 1930's-40's. With the movement for freedom the Muslim identity in the region (and also that of the Hindus) went into a state of transformation, reform and development. There are many factors associated with this development. In brief, this happened when the reproduction and thinking of Indian society encountered the condemnation, prejudice and chauvinism of its colonial rulers and their inbred bequest. Mainly, Muslims felt defamed (as did Hindus) by the British attacks on their masculinity which was seen as effeminate and thus pitiful. Muslims thus looked to the past, similar to Hindus, for explanations and facts that would disprove this. They considered their position in relation to a past golden era, and this then lad to an encompassing protest and call for emancipation.

The participation of women and their dominant contribution for the movement was remarkable. They not only aroused and motivated men into action in the fight against Indian subordination by the colonizers, but also delivered a vehicle that 
empowered transformation. The cultural conflict among subcontinent woman was one of the focal grounds in the struggle for a Muslim identity. Even so, regardless of the imagery used, a key issue in any related discussion whether women were seen as having any significance and meaning in Islamic reformation and transformation that occurred in India or not. It is important here to read the ideological difference in terms of the subjects, and if there was an interconnected identity to this. Likewise, it is relevant to examine whether these ideas came to a culmination in the formation of an Indian and Pakistani identity or not. Moreover, what is obvious in the women's inquiry is not merely their need to find space for a fresh identity to contest old arrangements, but also their roles in terms of philosophy, ideology and their presentation. It is also important in this study to look at whether women were supported by the Muslim movement in India, or simply adornments to the appearance of transformation. These issues progress, as Nathaniel Adams writes, through the representation from historical genealogy to contemporary development that emphasize on the influences of religious thoughts, practices, and actors in shaping social attitudes and "norms around gender" (Adams 2015, 2). The aim of this work is both to enlighten ongoing discourse and to sustain efforts to define productive paths forward on women's empowerment and education.

However, at the end of the nineteenth century, colonialism in India had been reorganized and justified in Britain by several philosophies and ideologies, with many issues regarding women being noted here. Gender was employed as part of a rationalization of European rule, along with the proposition that Indian women happened to live under the subjugation of local men (Minault 1998, 21-45). This status was considered to be grounded upon economics, racial subordination or cultural inferiority. The exercise of ceremonies and sacraments that were seen as abhorrent (such as to Sati $^{1}$ and early marriage), were regarded as especially brutal to the culture of the British. These incidents were, however, also exaggerated and said to be far more prevalent than they actually were. Sinha, in his book Colonial Masculinity, locates masculinity as the focus of colonial and nationalist politics in late nineteenth century India. Sinha places the investigation very precisely in the setting of an imperial social formation, investigating colonial masculinity not only against the background of social forces within India, but also as enclosed by and framing political, economic, and ideological shifts in Britain (Sinha 1995, 20-85). Considering the whole population of Indians as a solitary entity, the treatment of the local women by men was seen as an error in the generalized sense, and unmanliness was considered to be natural in Indian

1 Sati or suttee is an outdated Hindu funeral tradition where a widow immolates herself on her husband's pyre or commits suicide in another fashion soon after her husband's death (Gilmartin 1997, 141). 
masculinity. The colonizers thought and believed that there are countless factors behind this, such as, a poor diet, nonexistence of manly restraint, and a tropical climate. The general consequence of this was seen as a loss of male endurance and fortitude. Indian men had misplayed their sexual self-control and therefore were obliged to participate in so-called entertainments such as early marriage and/or child marriage, masturbation, and further actions that were seen as "unmanly" (ibid. 15-20). Apart from this, there are several other issues relevant to this study Sinha deals with in his book.

Consequently, the inference of such interpretations of Indian society was that the men of this region were sexually debauched, and therefore feeble, and were also too disobedient to govern themselves. It was considered that one of men's duties was to act as a protector and combatant in the sense of the European tradition of maleness, and thus it was the responsibility of British gentlemen to protect the troubled women of the Indian subcontinent. This view was also extended to white women, as seen in the framework of the Ilbert Bill of $1883^{2}$, which gave educated Indian men partial administrative rights. It was strongly contended by many whites in India, however, that such an arrangement was the doorway to sexual domination and the obliteration of a kingdom.

It is seriously meant that natives who practice polygamy treat their wives as caged birds, kept in the dark chiefly for the creation of sons... who immolate infants of tender age to marriage, who compel infant widows to remain widows till death-are as such competent to try European men and women? (ibid., 42-45)

\section{Religious Ideologies about Women's Education}

There was the impression in European imperialism that India was a realm that had collapsed into devastation. It was from this decentralization that nations such as Britain wanted to progress, but Indians seemed to have no involvement in this development. The motivation of both Hindu and Muslim nationalism was focused on this move towards renovation. At this significant turn, both principles and creeds supported the idea that India had misplaced its previous magnificence

2 The Ilbert Bill was a bill announced in 1883 under the supremacy of the Viceroy Lord Ripon and was transcribed by Sir C.P Ilbert, the legal member of the Viceroy's Council. As stated in the Act, Indian judges could try a European accused of a crime. Lord Ripon had a lengthy conversation with Sir CP Ilbert to modify the act, thereby favouring the Indians. This is named the famous Ilbert Bill or the White Mutiny (1883). Nevertheless, the overview of the bill ran into strong opposition in Britain and from British settlers in India, who played on racial tensions before it was passed in 1884 (Metcalf 2002, 120). 
and dropped into spiritual decay. Since the colonial background of the action of women had been employed so as to reinforce their regulation, Muslim reformism aimed to employ very similar notions to weaken its grip; a contrasting logic in favour of women, Islam, and India could disprove colonial propaganda (Whoopla) and contradictions. Corresponding to the many public publications of the British India who were nervous about the Ilbert Bill, the pro-Indian forces now had a form of capitalism and the stream of literature to present their own viewpoints and ideologies, which worked to promote nationalism and unity ${ }^{3}$.

The fact of the matter is that nationalism thinks in terms of historical destinies, while racism dreams of eternal contaminations, transmitted from the origins of time through an endless sequence of loathsome copulations: outside history (Anderson 1991, 149).

The concept of Islamic reform was not exclusive to the colonial system at the start of the twentieth century. The notion of a revitalization of Islamic sentiments and reappearance in a more virtuous age had been around for a long time, such as at the commencement and the conclusion of the Mughal Empire. In the repercussion of Mughal decay, writers like Shah Waliullah encouraged a revolutionary attitude to restructuring ${ }^{4}$. This subject would be recurrently discovered by Indian Muslims, aiming to revive the essential principles of Islam, suggesting not only that the Muslims of South Asia had drifted from a more honourable time, but also that the identity of the belief had changed by exposure to Indic civilizations that had no exact home in Islam. Contingent on who was referred to as the subject, women's enquiries with regard to Islam in South Asia were associated with a previous, healthier age, one which had been dishonoured by religious and social heterogeneity, as well as pluralism.

3 Anderson notes the developments that shaped the communities: the "territorialisation" of religious beliefs, the weakening of traditional kingship, the communication between capitalism and print, the improvement of vernacular languages-of-state, and shifting notions of time. He shows how an "originary" nationalism born in the Americas was modularly accepted by widespread movements in Europe, by the imperialist powers, and by the anti-imperialist confrontations in Asia and Africa (Anderson 1991).

4 As a reputed religious teacher of the eightteenth century, Shah Waliullah of Delhi was renowned as one of the chief philosophers from the age of fifteen. He assisted in reviving the Islamic awareness by channeling the streams of the Sufi spiritual heritage into traditional Islam and reverted to the fundamentals of Sufi experience in order to demonstrate that, fundamentally, Sufism is one discipline. He showed, for instance, that the long-standing supposition that Sufi principles were separated between Apparentism and Unity of Being was an alteration of appearance alone, the concluding creed of Ibn Arabi being seen as simply a less-advanced phase in the overall (Al-Dihlawi and Fry 1980, 14-97). 
The poet-philosopher-comparativist M. Iqbal ${ }^{5}$ considered education as inevitable for both males and females, thinking that: acquiring knowledge is a human need, which eventually helps in making the choice between good (khair) and bad (sharr), and between just (haqq) and unjust (batil) (Mas'ud 1986, 3-6). Iqbal appreciated intellect, but he critiqued contemporary thought for overreaching it at the expense of intuition or affection. He thought that the good man is imaginative and original, for creativity is the most valuable and unique gift of man (Saiyidain 1997). He must be able to deploy his intelligence to connect the forces of nature for his own good and also to escalate his knowledge and power.

Enslaved life is reduced to small rivulet.

Free it is like the boundless ocean. (ibid., 24)

Iqbal emphasized the prominence of freedom, which permitted an investigation into the environment, for the exercise of selection and discernment in the use of methods and substance, and for learning by straight experience. In spite of the importance of the individual, Iqbal did not disregard the role of the community and its culture in the give-and-take dynamics with the individual (Nor and Bahroni 2001, 23).

The individual exists in relation to the community.

Alone he is nothing.

The wave exists in the river.

Outside the river, it is nothing. (Saiyidain 1997, 24)

However, the appearance and representation of women offered in this development could be indiscriminate and generalized into two procedures. Firstly, women were beleaguered as products of the Indic civilization, surviving with a lifestyle inappropriate to Muslims. Secondly, women were out of regulation because of the Indic and colonial structure. Mutually, both of these issues characterized a noticeable symbol of moral deterioration in a time without Islamic regulation. Activists and reformers of the nineteenth century observed the "degeneration" of women in Islamic society as the creation of the Nawabi regime, summoning the appearance of hedonistic courtesans (Hadi 1961). A mutual thread in the argument over this degeneration was that Muslim women were spiritually and knowledgeably

$5 \quad$ Muhammad Iqbal (1877-1938) was an exceptional poet-philosopher born in India. He was, conceivably, the most powerful Muslim intellectual of the twentieth century. His philosophy, though eclectic and taking inspiration from Muslims thinkers such as al-Ghazali and Rumi and Western philosophers such as Nietzsche and Bergson, was engrained essentially ingrained in the Qur'an, which Iqbal read with the compassion of a poet and the perception of a mystic. Iqbal's philosophy and thinking is known as the philosophy of kbudi or Selfhood. 
underprivileged and the resources in which this could be addressed lay with education. Women were regarded as in a terrible necessity of being protected from their misrepresentation, misconception, and maltreatment lest their lack of awareness contaminate their children and all of the social order. It was the philosophy of how women should be educated and what the consequences would mean for the future of Islamic culture that these philosophers were arguing about.

There were many discussions in the society regarding women's education. Poets, such as Yusuf Gada ${ }^{6}$ attached the situation of women in society as one suggestive of offensiveness, one that needed to be resolved by their husbands and fathers and following the Persian conventions and customs. He ascribed this to Hinduism and exploitation of Islam, as seen in Sufism (Metcalf 2006, 103). There was a model in such disputes that saw Islamic women as disobedient children, and the errant women of Indic and British traditions as a disapproving other. Incarceration for the correction of women seemed too analogous to the approaches of their colonial rulers; the path to Islamic reform would thus embrace female education. Ulama (Islamic scholars) such as Maulana Ashraf Ali Thanawi ${ }^{7}$ and Sayyid Mumtaz Ali ${ }^{8}$ reasoned that women's education was vital because women had similar mental faculties as men and therefore had the capability to be educated if wanted. He also argued that renunciation of this ran counter to Islamic understanding, for it debased other members of the belief and encouraged their disgraceful maltreatment (Metcalf 2006, 105). Thanawi believed that men and women had their own typical behaviours as Muslims but women were particularly significant, for religious female figures such as, Fatima (daughter of Prophet Muhammad) followed the central values of Islamic beliefs. He also thought that an appropriate Indian Muslim woman displayed educated, modest behaviour, as all Muslims should, but also was proficient at activities within the domestic realm. His interpretation of women was different from the Western notion of the "Ladies of the Home", for he was endeavouring to locate men and women within a similar jurisdiction, not as masters of dissimilar domains. Thanawi did not consider women as perfect wardens of the home or endue with certain female gifts; they needed the plinth Victorian society place them upon. Men and women were thus notionally observed as similar, but had dissimilar duties.

6 Yusuf Gada was a Sufi poet who was a disciple of Shaikh Nasir ud-Din Muhammad Ciragh-i-Delhi. His views on education and moral issues were widely accepted. His book Gift was used in educational institutions as a textbook. (Hadi 1995, 629)

7 Ashraf Ali Thanwi (1863-1943) was an Islamic Indian intellectual of the Sunni Deobandi School. Maulana Ashraf Ali Thanwi was a strong supporter of the Muslim League. He and his followers provided their whole-hearted support to the mandate for the formation of Pakistan. (Khan 1988)

8 Sayyid Mumtaz Ali (1886-1935) was a popular example of a vernacular-using reformer. He was engaged in religious debate and published on religious controversies. Mumtaz Ali was a person of good repute for his pioneering role in Urdu journalism for women. (Jones 1992, 180) 
Mumtaz Ali agreed with Thanawi that men and women were alike and the same before Allah, and allowed a similar education. He endorsed the existing judgments on obedience to untruthful customs in Islam, and postulated that women had a more sophisticated place in Islamic law than they were seen as having, and the one way to address this was to practice of Islam back to its appropriate form, which required educating women. Though he too acknowledged women had a role in arranging the household and nurturing of children, this should not have disqualified them from having a similar education as men. Women as insulated, ill-informed individuals were an insult to Islamic ideas of learning, and purdab ${ }^{9}$ was not observed in association with the Shariat ${ }^{10}$; this would have simply encouraged modest behaviour which could be practical for both genders (Minault 1998, 20-50). He thought that when men and women were educated similarly under the Shariat, these inequalities would vanish. Correspondingly, Mumtaz Ali claimed that women were an essential piece of the Islamic distinctiveness and identity, and if men were not enthusiastic in working toward better self-government of them, they may well be powerless with regard to looking for a Muslim identity outside of India. To Mumtaz the individual was political, in that women were a sign of Islam's freedom or signified the sustained bondage to Indic traditions that debauched it.

On the other hand, Islamic writers, like Nazir Ahmad ${ }^{11}$ and Abdula Maududi ${ }^{12}$ emphasized the prominence of women's education in Islam as a tool of cultural congruence, coherence and the creation of a new social order. Maududi criticized the lifestyle of Western women as one that requested misapplication. Taking references from newspapers, investigations, and medical accounts of maltreatment from Britain, he supposed that the complexities and difficulties of gender could

9 Purdah is a religious and social exercise of female privacy widespread among some Muslim and Hindu communities in South Asia. It may have two forms: physical isolation of the sexes and the prerequisite that women cover their bodies in order to cover their skin and hide their appearance (Wilkinson-Weber 1999, 74).

10 Islamic law or Sharia law.

11 Nazir Ahmad known as "Diptee" (Deputy) Nazir Ahmad (1831-1912) was an Urdu writer, social and religious reformer, and scholar. He was concerned with Muslim women's education, and their lot in general. Most of his novels on an impeccable woman, who is both practical and erudite, and seen as a leader for young girls (Naim 1984, 290-314).

12 Abul A'la Maududi, known as Abula Maududi, (1903-1979) was an Islamist philosopher, jurist, journalist. His abundant works were written in Urdu, but then translated into English, Arabic, Hindi, Bengali, Tamil, Burmese and many other languages. He thought that politics was indispensable for Islam, and that it was essential to establish I and conserve Islamic culture from what he saw as the evils of secularism, nationalism, women's liberation, communism and socialism as they were the results of Western colonial imperialism and the Islamic world wanted to be intellectually sovereign, in an idea often called intellectual decolonization (Nasr 1996, 49). 
be simplified to three harmful factors that ran opposing to the natural order. These are the equality of women, the economic freedom of women, and unobstructed mingling of the sexes. This was an image of an animalistic society that exemplified the notion of moral deterioration (Metcalf 2006, 113). He attacked those he observed as emulators of Western culture, such as babus, who he called parrots of the British and the West. The way in which a well-ordered, appropriate society would be gained was from Islamic education, and he thought this advocated the "natural superiority" of husbands over their wives.

Therefore, Maududi asked and worked for education for women that was equivalent to that given to men, but this was an education that prepared them for a wife's role; education was thus a way of making a woman experienced. To Maududi, a woman's liberty was inevitably linked to the right to her husband's legacy and financial control, as well as the right to decline a marriage (although not in a contradiction of the wishes of her family). Since Maududi saw women as naturally open to emotional immoderation, purdah was not merely satisfactory, but to some degree should be sustained so as to uphold social order and, in astonishing irony given his repudiation of Western understanding, scientifically valid.

Since biologically woman has been created to bring forth and rear children, psychologically also she has been endowed with such abilities as suit her natural duties. This explains why she has been endowed with the natural feelings of love, sympathy, compassion, clemency, pity, and sensitiveness in an unusual measure. And since in the sexual life man has been made active and women passive, she has been endowed with these very qualities alone which help and prepare her for the passive role in life only...That is why she is soft and pliable, submissive and impressionable, yielding and timid in nature. (Maududi 1939, 120-1)

Regardless of Maududi's attack on Western ideas about women and the culture which he sensed had contaminated Islamic identity, his approach was very similar to that laid out Victorian ideas about women as children who needed the emotional and physical safety of men. Similar to Victorian "science", he even quoted the "derangement" of women based on menstruation, pregnancy, and panic as reasons to give them equivalent treatment. Corresponding to European and American ideas and fashions, Maududi's dream of education for Muslim women thus seemed more decorative and figurative than substantive.

Reorganizers and social reformers like Nazir Ahmad supported education for women as a crucial characteristic of the Shariat and an apparatus of social reform in the greater Indian society, nonetheless his opinions on female "emancipation" 
necessitated their domesticity and obedience. In Mirat al-'Arus he showed the idyllic learnedness of the female central character, Asghari, as a sophisticated and agreeable way to educate girls although always in on reputable, controlled terms, with the woman learning in her household and for no financial achievement (Lal 2008, 19). In the text, the polite, appropriate daughter, Asghari, teaches only girls from sharif families and not the others. The girls are acknowledged as exceptional with regard to sewing, stitching, cutting and dying clothes, as well as general housework. In this understanding, Asghari is shown not as a person in Mirat but more a paradigm of female education. The woman is cultured by education as the source of the Shariat in her arena, receptive a polite and obedient education that she can then pass on to her children. It was as a result of this perfect archetype that Ahmad reinforced the idea of the education of women as an apparatus of future understanding. This is seen in how Ahmad elucidates general view of Mirat,

I do not deny that too much learning is unnecessary for a woman, but how many women are there who acquire even so much as absolutely necessary?" Girls/women may never be able to read and write like boys/men, but they do need literacy "sufficient to meet [their] own requirements". (ibid., 26)

Ahmed believed that the Shariat and the sharif way of life would generate virtuous, representational citizens that appear as symbols. Skilled men offered reflection and action, while women deployed their education to perform with "tenderness and deep devotion" to them. To Ahmed the system was complex, as in spite of the obligation to educate women and free them from colonial and Indic traditions, men were still prioritized. "[Their] creation was merely to ensure the happiness of [men], and it is a woman's duty to keep a man happy...it is ignorant if a woman considers a man her equal (ibid., 23)." Apart from of philosophical discussions, the execution of women's rights in Islam with regards to India was surrounded by a combination of different viewpoints that expressed progressive policies with restrictions. Underneath the recognized Shariat, daughters were permitted to share their father's possessions and assets, an observation that was measured in compliance with the Qur'an and the Hadith in a nation where numerous communities experienced customary laws in its stead, ones that debarred women from any sort of ownership. These sorts of policies were not challenged by the Raj, since they benefited the rich who preserved their landholdings in this way (Minault 1998, 11-43).

Near the beginning of the twentieth century the alliance of ulama arose, represented by Muslim middle-class reformers, organisers, influencers and Westernised politicians with nationalist reactions and feelings. This coalition, though, is often 
presented as far more united then it actually was. We can note here the gatherings in 1910's, such as when the All-India Muslim Ladies' Conference demonstrated against legal unfairness and discrimination against women, as seen in divorce laws and polygamy. This received outrage in the Muslim press. More so than with the rhetoric of Thanawi and Ali for greater freedom against the background of Islamic society, by the time the formation of Pakistan was a possibility, it emerged that the wider perception of female liberty was more in line with that of Maududi and Ahmad, representative of the Islamic ethical order and a society apart from India.

Regulations and orders, such instance the Shariat Application Act of 1937, influenced the advance in women's rights desired. This also helped in articulating a Muslim identity in a legal construction that added vigour to the nationalist call for collectivity. In a satirical move, women placed themselves in an analogous sentiment to Muslim society as women in the West, using depictions and metaphors that supported the merits of their culture, but with no voice of their own. Women, while conferred with, were expected to concur (ibid., 30-40).

However, in Pakistan, the call for the education of women in Islamic society was and remains one of broken promises and empty words. Nowadays, the literacy of girls in the nation is still very low especially in regions like, Baluchistan and Khyber Pakhtunkhwa Province. Indeed, it is as low as three percent, as Amir Latif notes (Latif 2011). The principal reasons for this are because of both a wish for child labour in a poor country and cultural beliefs that are unenthusiastic about educating girls. For both reasons, parents frequently do not permit their daughters to be present at school. In extreme cases, religious fanatics have acid in the faces of girls who try and educate themselves despite their religious principles. Guaranteed education for women and girls as well as equal access to education in order to build stronger and more resilient communities, thus, remains a dream for many.

Gender equality in education is a basic human right - it is also essential to achieving sustainable development. In our increasingly globalized world, the societies that succeed best will be those which guarantee women and girls equal access to education, thereby giving them the skills and the opportunities to develop their talents and interests, so they can contribute to building stronger and more resilient communities. (Bokova 2017) ${ }^{13}$

Subsequent to the formation of Pakistan, women's inquiry was rapidly abandoned, with women being a sign of national and religious identity that was disconnected from India but no longer relevant when that state was formed. Nowadays,

13 Irina Bokova delivered at 37th Session of the UNESCO General Conference, Promoting Girls' and Women's Education for Gender Equality, in November 2013 (see Bokova 2014). 
courageous individuals like Mukhtaran Mai ${ }^{14}$ and Malala Yousafzai ${ }^{15}$ puts efforts into upholding institutions that promote education for girls and are under continuous attack, threats that go fundamentally uninvestigated and without punishment by the government. With transformed media attention, the women's inquiry in Pakistan has moved from one of South Asian identities to a worldwide level. The conventions of the West, in which Muhammad Ali Jinnah aimed to build Pakistan on more than a simply religious notion, have started to put the nation under the microscope. In any circumstances, the reasons for discrimination and signs of how the philosophies of freedom for Muslim women have been implemented are seen vividly with reference to the current and previous issues. Since these sorts of revelations come with a sense of disgrace and a longing to continue the work that started over a century before, a continuing fight against the very superstition the ulama condemned, and a fight for the religious acknowledgment of women as human beings.

According to Nathaniel Adams, equal opportunity, gender parity and the empowerment of women have long had a prominent position in dialogues about development in Bangladesh (Adams, 2015, 1), since the country (previously known as East Pakistan) achieved freedom after nine-month war. The country's 1971 sovereignty coincided with a greater spotlight on gender matters in international development primarily expressed via Women in Development policy and afterward reconceptualised as Gender in Development demonstrating growing acknowledgment of the socially built nature of gender functions and associations (ibid). The new Bangladeshi government and the quickly rising civil society saw women's empowerment as a central aim, and as, a reaction to the aggression against women during the Liberation War of 1971, as well as to gain financial support offered by foreign donors for programs aimed helping women. Certainly, reviewing development works in Bangladesh today (ibid 1), most schemes have clear stipulations of the effects on women.

14 Mukhtaran Bibi now recognized as Mukhtār Mai, is a Pakistani woman from the village of Meerwala of the Muzaffargarh District of Pakistan. In June 2002, Mukhtar Mai was the survivor of a gang rape as a form of honour vengeance, on the orders of a tribal council of the local Mastoi Baloch clan that was wealthier and more influential than her Tatla clan in that region. Even though custom would call on her to commit suicide after being raped, Mukhtaran spoke up, and pursued the case, which was publicized and circulated by both domestic and international media. Though the security of Mukhtaran, and her family and friends, has been in danger, she remains a candid advocate for women's rights. She initiated the Mukhtar Mai Women's Welfare Organization to assist support and educate Pakistani women and girls. (Kristof and Wudunn 2009)

15 Malala Yousafzai is a Pakistani activist for female education and the youngest-ever Nobel Prize laureate. She is well known for human rights advocacy, especially the education of women in Pakistan. 
However, there are grave and deep-rooted barriers to genuine and significant equal opportunity for women in Bangladesh. The country has, as Adams writes, one of the highest percentages of child marriage and juvenile motherhood in the world, and aggression against women remains an all-encompassing social reality, connected in part to the prevalence of dowries and uneven power dynamics in the home.

The increasing participation of women to the work force, particularly in the garment sector, has offered women a newfound economic agency and increased mobility, but these achievements have been tempered by unsafe working conditions, long hours, and uncertain terms of employment. (Adams 2015, 1)

Active and working women also experience a double load of household tasks and paid income work, as things have changed slowly in the domestic sphere. The shifting social function of women, with their growth of prospects in terms of education and employment, has appeared as the main fault line in the progressively more "polarized atmosphere between secular and religious social powers" (ibid 1).

\section{Religious Viewpoints on Gender in South Asia-Various Historical Aspects}

Considering the devoted communities and social divisions at its centre, male dominated customs and approaches have been a lasting characteristic of South Asian society. Religious points of view are thus frequently employed in efforts to uphold the uneven position of men and women in economic, political, and social realms (ibid 2). Besides, it is significant to note that religious traditions in South Asia are not "monolithic" in their views of gender, which are the consequences of miscellaneous historical practices and ideological manipulations (ibid). Nowadays, as before, there are substantial inconsistencies, within and among religious groups concerning the social status of women. At different periods and in different circumstances religious influences have been employed to validate male supremacy over women and, on the other hand, to call for more reasonable gender associations and representations.

As confirmation of the immense range and variety of religious views on gender parity, some of the well-established calls to increase women's privileges in nineteenth century South Asia came from religious leaders of Islam, as discussed 
earlier, and also from Hindus, such as the reformer Ram Mohan Roy ${ }^{16}$, originator of the Brabmo Samaj, who was notably influential in the elimination of sati. Later, his descendant Keshad Chandra Sen ${ }^{17}$ wanted to ended purdah and polygamy. $\mathrm{He}$ also initiated move to abolish child marriage and permit women to inherit property, and widows to get married again (Mitra 2007). This period of time saw substantial legal and social progress for women. Intellectuals and other influential persons, nonetheless, note the paternalistic character of such reforms, indicating that women infrequently had a voice or action in these debates (Shehabuddin 2008). South Asia is a region settled by a Muslim population, but the approach towards this tradition and even the elucidation of the sacred texts varies from region to region. This, somehow, has been the circumstance since Islam's arrival on the subcontinent. In Afghanistan, Islamic ideologies have often been used by leaders to govern and suppress the lives of women, Islam cannot be overlooked in the democratization of Afghanistan, however, as it plays too prodigious a role in society (Kissane 2012, 10-28). Throughout the efforts for Indian sovereignty, a standard inspiration for such reforms was to adopt the modern features of the West and therefore destabilize the ethical rationalisation for colonial intrusion into Indian society (Murshid 1983).

According to Adams, Islamic restructuring, transformation and reform movements have had a profound effect on fundamental gender norms in South Asia (Adams 2015,2). The muscular nature of South Asian (Indian, Pakistani, Afghani and Bengali) Islam put it at the centre of many such actions since the nineteenth century. The Islamic Republic of Afghanistan represents a difficult backdrop in which to observe gender roles and relations, and women's education in particular, as such things entrenched in the country's history and religious ideology. The democratisation of education necessitates a pluralistic education model that includes State and nongovernmental sectors, as well as secular and non-secular institutions, making it accessible to the highest number of Afghans possible (Kissane 2012,10-28). Education that teaches and encourages critical thought, ijtibad, and introduces concepts of gender equality — supported by Qur'anic scholarship led by Islamic feminists - is imperative. In contrast to Hindu reformers of the time, these religious actions and representations are more focused on internal rejuvenation and a return

16 Ram Mohan Roy (1772-1833) was the creator of the Brahmo Sabha movement in 1828, which produced the Brahmo Samaj, a powerful socio-religious reform movement. His authority was obvious in the fields of politics, public administration and education and religion. He was well-known for his efforts to institute the abolishment of the practice of sati. Ram Mohan Roy's influence on modern Indian history was a revitalization of the pure and moral principles of the Vedanta school of philosophy as originated in the Upnishads (Sastri 1974).

17 Keshab Chandra Sen (1838-1884) was an Indian Bengali Hindu philosopher and social reformer who endeavored to integrate Christian theology within the structure of Hinduism (Sastri 1974). 
to orthodoxy (Adams 2015, 10). Their attitude to the colonial authorities-and the supposed introduction of and obligation to follow Western social norms-was unsympathetic, especially in relation to gender (Hassan 2011, 155-67). Islamic reformers placed an emphasis on the piousness and moral qualities of women, and praised them for exemplifying the family and society.

Paying attention to the function of women in the diffusion of "morals and values, Islamic restoration efforts" have in recent years started to highlight women's religious education with the intention of promoting piousness and appropriate religious observations (Adams 2015, 2-4). Till recent times, the majority of women in the region had little access to proper education, or to religious matters. Excluded from ceremonial worship in the mosque, women frequently took part in syncretic and unconventional religious observations in the home or at local holy places, especially in the countryside. The supposed spiritual and ethical vices of South Asian Muslim women in this regard were claimed to be an existential danger to Islamic society. A number of reformers thus saw women as possible "enemies from within" (Shehabuddin 2008). At the same time as this has been used as the principal rationalization for keeping rigid social control over women, it also requires same admittance to Islamic education, and can to a degree clarify the eagerness of many madrasas $^{18}$ to open entry to girls, following government actions to attain gender equality in education.

As observed through a few developments over time, the Sufi way of life and customs that symbolize some of the initial versions of Islam in South Asia, have normally permitted complete and more equivalent contributions by women in religious life, despite the fact that gender norms differ extensively across $\mathrm{Suf}$ communities within the region. As seen in practice, Mazars, the mausoleum holy places to Sufi saints, as Adams suggests, are not subject to the rigid gender isolation of Indian and Bangladeshi mosques. In several Sufi groups women also have leading positions (ibid 2-4).

Characteristically portrayed as a more spiritual facet of Islam, Sufis promotes a direct association with the celestial, which is frequently accomplished through music and dance (Adams 2015, Ahmed 2010). These sorts of unconventional exercises have led to important points of disputation with conventional reformers and leaders. Nevertheless, the appearance of feasible substitute narratives to the typical Islamic dialogue on gender associations, as embedded in Sufi mores, has fundamentally been dissuaded due in part to the strong separations between instructions (tariqa) and the well-established inward religious focus of various Sufi movements.

18 Islamic educational institution 
The apprehension, nervousness and anxiety between sacred traditionalists and secular feminists are very old phenomena. Members of South Asia's vocal and active women's associations, ideologically ingrained in Western feminism, were ferocious antagonists of the government supported Islamization of the 1980s (e.g. in Bangladesh) where religion was seen as the key force in the domination of women in South Asia. It has been noted that South Asian women's communities are principally constructed of urban middle- and upper-class women, reflecting the harsh class separations in South Asian society (Adams 2015). ${ }^{19}$ This region itself is highly diversified and there is a diversity in the women's educational levels across regions such as in the Republic of India (for example, in Kerala almost a decade ago the literacy rate among Muslim women was about $85 \%$ ), and there is also a high proportion of highly educated Muslim women among the elites in many areas. This profound class separation limits the options for impoverished and rural women, many lot of whom idealize and imagine responses to subjugation in more varied ways than those who force the debate on women's rights and opportunities nationally. The hostile attitude of secular women's communities toward religion has in some instances caused barriers with poor and religious women making room for Islamists to defend these communities. Certainly, Islamist communities together with those connected with the greater Islamic political party are trying to move towards the more rights-focused speech of the women's interest groups, setting out dialogue that describes the rights of women as those openly approved in the Qur'an, which are deduced as balancing rather than equivalent to those of men. These communities give the impression of being connected to the Middle East in building an "Islamic modernity", and perceive the veil as an indicator of the contemporary and authorized Muslim woman, which in many cases creates disputes within nations (Rojario 2006, 368-80).

In this ideological stratum there has been a momentous propagation of women's taleem (Qur'anic conversation) among the middle class, anticipated as nurturing a "correct" perception of Islam and Muslim womanhood (Huq 2008, 457-88; Adams 2015, 8-10). Several of these groups are connected with Jamaate Islami and their educational wing, Islami Chhatri Sangstha, over and above the already accepted religious movements such as Tablighi Jamaat (Adams 2015). Several others exist without an unambiguous association. These women's taleem are ingrained in a "textually-based piety" that in various instances discards vital South Asian (Indian, Pakistani and Bengali) cultural demonstrations of womanhood, together with the performing of folk songs. In mirroring the roles, hopes and prospects of woman at home and in society, and restructuring their identities as women, taleem associates are forms of organization, but normally without the wish to deal with

19 Also see Shehabuddin 2008. 
or confront patriarchy (ibid. 2011, 225-39). In line with the well-established secular nature of the women's movement in South Asia, the still developing Muslim women's communities, such as Musawah, which employ a scriptural foundation to confront gender discrimination, remain unstable.

\section{Conclusion-Anticipating the Future}

Compare to earlier times, South Asia has made substantial progress toward gender parity, and this is mirrored in several social and economic parameters. Nonetheless, the South Asian experience provides several views of both conformist and traditional attitudes towards women's empowerment and education. Such advances can make it difficult to distinguish how far gender matters are deep-rooted in specific socio-cultural circumstances, and therefore can make it easy to disregard issues that can obscure or eventually weaken educational liberty, empowerment or efforts at greater equality. Certainly, in spite of substantial achievements, entrenched patriarchal social norms still triumph in many situations, and especially in the region's multifaceted religious and cultural traditions.

The experiences of South Asia indicate the need for improved knowledge about of the manners and behaviours of men, in order to encourage them to accomplish gender parity and educational liberty. According to Adams, this reflects the findings of an assortment of research efforts, such as those published by the "International Center for Research on Women, Promundo, MenEngage, and Sonke Gender Justice" (ibid 8). This mounting body of works highlights the necessity for plans that stress the dynamics between women and men in contrast to keeping women in seclusion. Men are able to and must take up a decisive role in shifting views of maleness that are destructive to women, and so eventually changing the gender norms in their communities.

As discussed in this investigation, religious leaders and reformers have a unique function to play in such approaches based on their social persuasion and ethical roles. While there are ideological gaps on gender subjects and women's education, various local development initiatives and rights groups (both civil and human rights) are working towards persuading imams and other spiritual figures to change. Women's communities and interest groups frequently recognize partnerships with spiritual leaders as ways of promoting their social rights and abilities, although they still face many obstacles.

Religious and spiritual figures have been occupied in various gender-related initiatives in South Asia, signifying the aim to adopt a number of strategies to reduce 
the social and ideological gaps over these subjects. The vigorous contributions of religious reformers, ulama and imams can be observed as having performed a vital role in obtained about wider social recognition for family issues, girl's education and other topics in South Asia and the decrease in the fertility rate. Moreover, in recent times, more than a few organisations, working together with UNICEF, UNFPA, and the Asia Foundation, have tried to engage religious leaders, philosophers, imams and other religious figures through the government' and non-government' Islamic and non-Islamic organisations on matters varying from violence against women to women's education and dowries. The results have thus far been positive, although such initiatives are still too small and ineffective for large scale change. Problems also linger with regard to the ability of such an agenda to connect with more conventional religious leaders, as well as the types of issues that can be dealt with through an Islamic framework. At the same time as religious leaders have been enthusiastic in speaking against dowries using scriptural points and views, several claim that there is no the similar kind of religious basis to combat child marriage, for instance.

South Asia's understanding of educational liberty and Islamic education (for instance madrasas) for girls shows that the possible influence of religious involvement is huge, but - predominantly on subjects of gender empowerment and secular education - can be complicated. Conventional "religious groups" in South Asia, as Adams shows, have long made allegations of "cultural imperialism" over the introduction of Western social approaches, norms and ideas about rights, education and empowerment (Adams 2015, 8). It is apparent, however, that even if the aim is to better understand the structure and continuation of prejudiced and bigoted social exercises, norms, and approaches, and so to realise the hopes of women in the region, then appealing to religious actors, ulama and philosophers is key. A profound and more distinct discourse that highlights the religious and cultural aspects of gender can help women's rights campaigners as they push for more even-handed and equivalent gender relations in South Asia.

\section{References}

Adams, Nathaniel. 2015. "Religion and Women's Empowerment in Bangladesh." Occasional Paper, Berkley Center for Religion, Peace and World Affairs. 1-10. Ahmed, Imtiaz. 2010. Sufis E' Sufism: A Closer Look at the Journey of Sufis to Bangladesh. Singapore: Middle East Institute.

Al-Dihlawi, Wali Allah, and Dennis Butler Fry. 1980. Sufism and the Islamic tradition: the Lamahat and Sata'at of Shah Waliullah, edited by Dennis Butler Fry, 14-97. London: Octagon Press. 
Anderson, Benedict. 1991. Imagined Communities: Reflections on the Origin and Spread of Nationalism. New York: Verso.

Bokova, Irina. 2014. "Delivered Speech on the Conference on "Girls' and Women's Right to Education: Overview of the Measures Supporting the Right to Education for Girls and Women reported on by Member States." UNESCO Report 2014.

Gilmartin, Sophie.1997. "The Sati, the Bride, and the Widow: Sacrificial Woman in the Nineteenth Century." Victorian Literature and Culture 25 (1): 141.

Hadi, Mirza Muhammad. 1961. Umrao Jan Ad (Courtesan of Lucknow), translated by Khushwant Sign and M.A. Husain. Bombay: Orient Longman.

Hadi, Nabi. 1995. Dictionary of Indo-Persian Literature. New Delhi: Abhinav Publications.

Hassan, Mubashar. 2011. "Historical Developments of Political Islam with Reference to Bangladesh." Journal of Asian and African Studies 47 (2): 155-67.

Huq, Maimuna. 2008. "Reading the Qur'an in Bangladesh: The Politics of 'Belief among Islamist Women.” Modern Asian Studies 43 (3): 457-88.

Huq, Samia. 2011. "Piety, Music and Gender Transformation: Reconfiguring Women as Culture Bearing Markers of Modernity and Nationalism." Inter-Asia Cultural Studies 12 (2): 225-39.

Jones, Kenneth W. 1992. Religious Controversy in British India: Dialogues in South Asian Languages. Albany: SUNY Press.

Khan, Shafique Ali. 1988. The Lahore Resolution: Arguments for and against: History and Criticism. London: Royal Book Co.

Kissane, Carolyn. 2012. "The Way Forward for Girls' Education in Afghanistan." Journal of International Women's Studies 13 (4): 10-28.

Kristof, Nicholas, and Sheryl Wudunn. 2010. Half the Sky. London: Virago.

Lal, Ruby. 2008. "Gender and sharafat: Re-reading Nazir Ahmad." Journal of the Royal Asiatic Society 18 (1): 15-30.

Latif, Aamir. 2011. "Alarming Situation of Education in Pakistan." UNESCO. Accessed July 10, 2017. http://www.unesco.org/education/efa/know_sharing/grassroots_stories/pakistan_2.shtml.

Maududi, Abduala. 1939. Purdah and the Status of Women in Islam. Lahore: Islamic Publications.

Mas'ud, Khalid.1986. Iqbal's Reconstruction of ijtihad. Lahore: Institute of Islamic Culture.

Metcalf, Barbara. 2006. Islamic Contestations: Essays on Muslims in India and Pakistan. New York: Oxford University Press.

Metcalf, Barbara D., and Thomas R. Metcalf. 2002. A Concise History of India. Cambridge: Cambridge University Press. 
Minault, Gail. 1998. "Women, Legal Reform, and Muslim Identity in South Asia." In Jura Genitum: Center for Philosophy of International Law and Global Politics, edited by Claudio Agustino, Anil Mishra and Antonella Roninone, 21-45. Accessed July 10, 2017. http://www.juragentium.unifi.it/en/surveys/ $\mathrm{rol} /$ minault.htm.

Mitra, Priti Kumar, ed. 2007. "Hindu Reform Movements in the Nineteenth Century in Islam." In History of Bangladesh 1704-1971: Social and Cultural History, edited by Sirajul Islam. Dhaka: Asiatic Civil Military Press.

Murshid, Ghulam. 1983. Reluctant Debutante: Response of Bengali Women to Modernization, 1849-1905. Rajshahi: Sahitya Samsad.

Naim, CM. 1984. "Prize Winning Adab: A study of Five Urdu Books Writing in Response to the Allahbad Government Gazette Notification.” In Moral Conduct and Authority: The Place of Adab in South Asia Islam, edited by Barbara Metcalf, 290-314. Berkley and Los Angeles: University of California Press.

Nasr, Vali. 1996. Mawdudi and the Making of Islamic Revivalism. New York: Oxford University Press.

Nor, Mohd Roslan, and Imam Bahroni. 2011. "Iqbal's Philosophy on Islamic Education: A Historical Perspective.” Global Journal Al-Thaqafah (GJAT) 23.

Rozario, Santi. 2006. "The New Burqa in Bangladesh: Empowerment or Violation of Women's rights?" Women's Studies International Forum 29: 368-80.

Saiyidain, Khwaja Ghulam.1977. "Iqbal's educational philosophy." Lahore: Sh. Muhammad Ashraf.

Sastri, Sivanth. 1974. History of the Brahmo Samaj. Calcutta: Sadharan Brahmo Samaj Publication.

Shehabuddin, Elora. 2008. Reshapping the Holy: Democracy, Development, and Muslim Women in Bangladesh. New York: Columbia University Press.

Sinha, Mrinalini. 1995. Colonial Masculinity: The "Manly Englishman" and the "Effeminate Bengali" in the Late Nineteenth Century. Manchester: Manchester University Press.

Wilkinson-Weber, Clare M. 1999. Embroidering Lives: Women's Work and Skill in the Lucknow Embroidery Industry. Albany: SUNY Press. 